\title{
PENGARUH BIAYA KUALITAS TERHADAP PENJUALAN PADA PT. GUARDIAN PHARMATAMA
}

\author{
Rilla Gantino ${ }^{1}$ \\ Universitas INDONUSA Esa Unggul, Jakarta \\ Erwin $^{2}$ \\ Universitas INDONUSA Esa Unggul, Jakarta
}

\begin{abstract}
This is an empirical research to determine the influence of the independent variable quality cost to the dependent variable sales. A T-test on prevention cost, valuation cost, internal failure cost, and external failure cost showed significant influence on sales. An F-test on prevention cost, valuation cost, internal failure cost and external failure cost also showed significant influence on sales. Regression analysis was done using the multiple linear regression equation $\mathrm{Y}=-240710057,3+496,753 \mathrm{X} 1+$ 411,237 X2 + 38,384 X3 + 21,283 X4. Regression analysis showed positive that prevention cost, valuation cost, internal failure cost, and external failure cost had a positive influence on sales, which indicates that increasing costs of quality leads to increase in sales. A coefficient determination test $(\mathrm{Kd})$ showed that $95 \%$ of quality cost contributes to sales; the remaining $5 \%$ is influenced by factors other than cost of quality.
\end{abstract}

Keywords: quality cost, sales.

\begin{abstract}
ABSTRAK
Penelitian ini bertujuan untuk memberikan bukti empiris mengenai pengaruh variabel independent (biaya kualitas) terhadap variabel dependen (penjualan). Dari hasil uji t untuk biaya pencegahan, biaya penilaian, biaya kegagalan internal dan biaya kegagalan eksternal

${ }^{1,2}$ Rilla Gantino adalah dosen Universitas INDONUSA Esa Unggul

(rilla.gantino@indonusa.ac.id), Erwin adalah alumni Universitas INDONUSA Esa Unggul.
\end{abstract}


berpengaruh secara signifikan terhadap penjualan. Dari hasil uji F untuk biaya pencegahan, biaya penilaian, biaya kegagalan internal, dan biaya kegagalan eksternal dapat disimpulkan bahwa biaya pencegahan, biaya penilaian, biaya kegagalan internal, dan biaya kegagalan eksternal berpengaruh secara signifikan terhadap penjualan. Dari hasil analisa regresi diperoleh persamaan regresi linear berganda, Y $=-240710057,3+$ 496,753 X1 + 411,237 X2 + 38,384 X3 + 21,283 X4, persamaan regresi tersebut menunjukkan bahwa pengaruh biaya pencegahan, biaya penilaian, biaya kegagalan internal, dan biaya kegagalan eksternal terhadap penjualan adalah positif yang berarti kenaikan biaya kualitas akan mengakibatkan kenaikan pula terhadap penjualan. Hasil uji koefisien determinasi (Kd) menunjukkan biaya kualitas memiliki kontribusi terhadap penjualan sebesar $95 \%$ sedangkan sisanya sebesar $5 \%$ dipengaruhi oleh faktor-faktor lain selain biaya kualitas.

Kata kunci: biaya kualitas, penjualan.

\section{PENDAHULUAN}

Dengan berkembangnya perekonomian sekarang perusahaan harus mampu bersaing dengan perusahaan farmasi lain yang setingkat seperti PT. Otto Pharmaceutical Industries, PT. Novel Pharma, dan lain-lain. Manajemen perusahaan harus selalu mengadakan penyesuaian terus menerus mengikuti perkembangan untuk dapat memenangkan persaingan yang sangat ketat, begitu pula dengan penjualan.

Penjualan merupakan salah satu indikator paling penting dalam sebuah perusahaan, karena penjualanlah yang dapat menghasilkan laba untuk sebuah perusahaan. Bila tingkat penjualan yang dihasilkan oleh perusahaan tersebut besar, maka laba yang dihasilkan perusahaan itu pun akan besar pula sehingga perusahaan bertahan dalam persaingan bisnis dan dapat mengembangkan usahanya. Mereka harus dapat meningkatkan keunggulan kompetitif, karena hal ini sangat diperlukan di dalam menghadapi persaingan usaha untuk itu perusahaan harus dapat menciptakan produk yang berkualitas tinggi. Oleh sebab itu manajemen bertanggung jawab untuk menjaga, mempertahankan dan meningkatkan kualitas produk agar lebih mampu menyehatkan masyarakat dan mampu bersaing di pasar. 
Perusahaan yang menjadikan kualitas sebagai alat strategi akan mempunyai keunggulan bersaing terhadap pesaingnya dalam menguasai pasar, karena tidak setiap perusahaan mampu menciptakan kualitas yang baik. Untuk memenangkan persaingan perusahaan dituntut menghasilkan produk dengan kualitas tinggi, harga wajar dan pengiriman tepat waktu. Seperti yang telah dilakukan oleh perusahaan dengan menciptakan berbagai macam jenis produk obat dengan berbagai merek seperti Flutab yang bersaing dengan merek Fluzep dari PT. Otto Pharmaceutical Industries, Nulacta yang bersaing dengan merek Prolacta dari PT. Novel Pharma, dan lain-lain. Untuk itu, perusahaan harus berusaha untuk meningkatkan kualitas produk tanpa adanya kenaikan biaya dan harga jual tetap kompetitif. Biaya yang dikeluarkan oleh perusahaan dalam upaya meningkatkan kualitas produk atau mencapai standar kualitas yang telah ditetapkan disebut sebagai biaya kualitas. Biaya kualitas didefinisikan sebagai biaya-biaya yang timbul karena kualitas suatu produk rendah, yang memungkinkan terjadi atau yang sudah timbul.

Masalah yang dihadapi oleh perusahaan adalah adanya anggapan bahwa tingginya biaya kualitas yang dihasilkan karena meningkatnya penjualan. Sebaliknya dengan turunnya biaya kualitas akan menurunkan penjualan. Dalam jangka panjang produk yang tidak memenuhi kebutuhan konsumen akan segera ditinggalkan, akibatnya penjualan akan menurun sehingga laba yang diperoleh perusahaan semakin kecil. Untuk mengatasi masalah diatas, dalam dunia usaha dewasa ini kualitas telah menjadi bagian dari strategi bisnis untuk meningkatkan keunggulan bersaing. Tetapi dalam melaksanakan program peningkatan kualitas, perusahaan harus tetap memperhatikan efisiensi biaya, dimana perusahaan mampu menghasilkan produk yang berkualitas namun dengan harga jual yang tetap kompetitif. Dengan kualitas yang baik dan harga jual yang kompetitif maka penjualan akan mengalami peningkatan.

\section{IDENTIFIKASI DAN PEMBATASAN MASALAH}

\section{Identifikasi Masalah}

Dalam mengidentifikasi masalah, penulis mengemukakan semua masalah yang mungkin timbul berkaitan dengan penelititan ini diantaranya :

a. Apakah peningkatan biaya kualitas diikuti juga oleh peningkatan penjualan. 
b. Apakah peningkatan penjualan disebabkan oleh faktor biaya kualitas saja atau ada faktor-faktor lain.

c. Apakah jika biaya kualitas naik penjualan akan mengalami penurunan.

d. Apakah selama ini retur barang menyebabkan penjualan mengalami penurunan atau tidak maksimal.

e. Apakah biaya kualitas dan penjualan selalu naik terus menerus setiap tahunnya.

\section{Pembatasan Masalah}

Berdasarkan identifikasi di atas, penulis hanya membatasi masalah pada laporan biaya kualitas gabungan untuk semua produk yang dihasilkan karena keterbatasan perusahaan dalam membuat laporan biaya kualitas perproduk dan laporan keuangan khususnya pada laporan penjualan selama 5 (lima) periode per bulan dari tahun 2004 sampai dengan tahun 2008 pada PT. Guardian Pharmatama

\section{Perumusan Masalah}

Berdasarkan uraian diatas, dengan kualitas yang baik dan harga jual yang kompetitif maka penjualan akan mengalami peningkatan. Perusahaan mengharapkan laba yang diperoleh besar dengan meningkatnya penjualan, maka rumusan masalah pada penelitian ini adalah sebagai berikut :

1. Apakah terdapat pengaruh biaya pencegahan terhadap penjualan pada PT. Guardian Pharmatama?

2. Apakah terdapat pengaruh biaya penilaian terhadap penjualan pada PT. Guardian Pharmatama?

3. Apakah terdapat pengaruh biaya kegagalan internal terhadap penjualan pada PT. Guardian Pharmatama ?

4. Apakah terdapat pengaruh biaya kegagalan eksternal terhadap penjualan pada PT. Guardian Pharmatama?

5. Apakah terdapat pengaruh biaya pencegahan, biaya penilaian, biaya kegagalan internal, \& biaya kegagalan eksternal secara bersama-sama terhadap penjualan pada PT. Guardian Pharmatama ?

\section{LANDASAN TEORI}

\section{Biaya Kualitas}

Menurut Garrison, et al (2006), pengertian Biaya Kualitas adalah : 
"Semua biaya yang harus dikeluarkan karena adanya barang cacat" Menurut Hansen dan Mowen (2005), definisi Biaya Kualitas adalah :

"Biaya-biaya yang timbul karena mungkin atau yang telah terdapat produk yang buruk kualitasnya”

Jadi berdasarkan pengertian-pengertian di atas dapat didefinisikan bahwa biaya kualitas adalah biaya yang dikeluarkan oleh perusahaan dalam rangka meningkatkan kualitas produk atau mencapai standar yang telah ditetapkan. Biaya kualitas perlu dikelola sedemikian rupa untuk mencapai suatu tingkat kualitas agar produk yang dibuat atau jasa yang diserahkan sesuai dengan spesifikasi rancangan dan bebas dari cacat atau masalah yang akan mempengaruhi penampilan atau kinerja yang diukur dengan kesesuaiannya terhadap keinginan pelanggan.

Menurut Vincent Gasperz (2006) mengemukakan biaya kualitas sebagai berikut :

\section{a. Biaya Pencegahan (Prevention Cost)}

Biaya pencegahan adalah biaya yang dikeluarkan untuk mencegah terjadinya cacat dalam produk atau jasa yang dihasilkan oleh perusahaan. Dengan demikian, semakin besar biaya pencegahan yang dikeluarkan, maka jumlah produk cacat yang dihasilkan akan berkurang dan biaya kegagalan semakin kecil.Biaya-biaya yang termasuk dalam biaya pencegahan diantaranya biaya-biaya yang dikeluarkan untuk :

1) Perencanaan Kualitas (Quality Planning)

2) Penelaahan Produk Baru (New Products Review)

3) Pelatihan (Training)

4) Pengendalian Proses (Process Control)

5) Pengumpulan dan Analisis Data Kualitas (Quality Data Acquistion and Analysis)

6) Pelaporan Mutu (Quality Reporting)

7) Proyek Penyempurnaan Mutu (Improvement Project)]

b. Biaya Penilaian (Appraisal Cost)

Biaya penilaian adalah biaya yang dikeluarkan untuk menentukan apakah produk dan jasa telah memenuhi persyaratan kualitas yang telah ditetapkan. Tujuan utama dari fungsi penilaian ini adalah untuk 
menghindari terjadinya kesalahan dan kerusakan produk sampai ke tangan konsumen. Biaya-biaya yang termasuk dalam biaya penilaian adalah :

1) Inspeksi Bahan-bahan

2) Inspeksi dan Pengujian

3) Pemeliharaan Ketetapan Alat Pengujian Kualitas

4) Bahan dan Jasa yang Digunakan

5) Evaluasi Persediaan

c. Biaya Kegagalan Internal (Internal Failure Cost)

Biaya kegagalan internal adalah biaya yang dikeluarkan karena terjadinya ketidaksesuaian produk dengan spesifikasi kualitas yang telah ditetapkan namun sudah dapat dideteksi sebelum produk dikirim ke pelanggan. Yang termasuk biaya ini adalah :

1) Sisa Bahan

2) Pengerjaan Ulang atau Perbaikan

3) Pengujian Kembali

4) Down Time

Down Time merupakan biaya karena adanya fasilitas menganggur sebagai akibat kesalahan atau kerusakan produk. Pada beberapa perusahaan biaya ini sangat besar dan diabaikan.

5) Analisis Kegagalan

6) Disposition

Disposition merupakan kerugian karena memperoleh keuntungan yang lebih rendah dibandingkan dengan keuntungan yang diperoleh apabila pengendalian kualitas ditingkatkan.

d. Biaya Kegagalan Eksternal (External Failures Cost)

Biaya kegagalan eksternal adalah biaya yang dikeluarkan karena terjadinya ketidaksesuaian produk dengan spesifikasi kualitas yang telah ditetapkan, namun baru dapat dideteksi setelah produk berada di tangan pelanggan. Biaya ini merupakan biaya yang paling merugikan, karena dapat menyebabkan reputasi perusahaan buruk, kehilangan pelanggan dan pangsa pasar. Tetapi biaya ini dapat hilang apabila perusahaan tidak menghasilkan produk cacat atau rusak. Yang termasuk biaya kegagalan eksternal adalah :

1) Penanganan Keluhan Pelanggan

2) Retur Barang 
3) Biaya Garansi

4) Potongan Harga

"Sebagai langkah awal dalam program perbaikan kualitas, perusahaan menyusun laporan biaya kualitas yang memberikan sebuah perkiraan adanya konsekuensi keuangan dari tingkat cacat produk yang ada di perusahaan. Laporan biaya kualitas menguraikan biaya pencegahan, biaya penilaian, dan biaya kegagalan internal dan eksternal, yang timbul dari tingkat kecacatan produk dan jasa yang dihasilkan oleh perusahaan saat ini. Manajer sering kali terkejut dengan besarnya biaya-biaya ini”

Pentingnya biaya kualitas terhadap segi keuangan perusahaan dapat lebih mudah dinilai dengan menampilkan biaya-biaya kualitas berikut sebagai persentase dari penjualan aktual. Tampilan dibawah ini, sebagai contoh, melaporkan biaya kualitas yang bersifat umum. Mengacu pada prinsip yang berlaku umum, bahwa biaya kualitas sebaiknya kurang dari 2,5 persen, Perusahaan memiliki kesempatan yang baik untuk meningkatkan laba dengan mengurangi biaya kualitas. Akan tetapi, tentu saja pengurangan biaya ini seharusnya melalui perbaikan kualitas.

"Laporan biaya kualitas memiliki beberapa kegunaan. Pertama, 'informasi biaya kualitas membantu para manajer melihat keuntungan finansial dari cacat. Para manajer biasanya tidak sadar dengan besarnya biaya kualitas mereka karena biaya-biaya ini melintasi batas departemen dan tidak dapat ditelusuri dan diakumulasi secara normal oleh sistem biaya. Maka dari itu, ketika pertama kali disajikan dengan laporan biaya kualitas, para manajer sering kali terkejut dengan jumlah biaya yang diakibatkan oleh kualitas yang buruk".

Kedua, informasi biaya kualitas membantu para manajer mengidentifikasikan pentingnya masalah-masalah kualitas yang dihadapi perusahaan.

Ketiga, informasi biaya kualitas membantu para manajer melihat apakah biaya-biaya kualitas di perusahaan mereka didistribusikan secara tidak baik. Umumnya, biaya-biaya kualitas seharusnya lebih didistribusikan ke arah aktivitas-aktivitas pencegahan dan penilaian dan kurang diarahkan ke kegagalan. 
Tabel 1. Bentuk Umum Laporan Biaya Kualitas Bulanan

\begin{tabular}{|c|c|c|}
\hline Deskripsi & $\begin{array}{c}\text { Rp. } \\
\text { /Bulan }\end{array}$ & $\begin{array}{c}\text { Persen dari } \\
\text { Biaya Total } \\
(\%)\end{array}$ \\
\hline $\begin{array}{c}\text { Biaya Pencegahan (Prevention Cost) } \\
\text { - } \quad \text { Administrasi Pengendalian Kulitas } \\
\text { - } \quad \text { Rekayasa Pengendalian Kualitas } \\
\text { - Perencanaan Kualitas ....... } \\
\text { • Pelatihan } \\
\text { Biaya Total Pencegahan (total Prevention Cost) }\end{array}$ & & \\
\hline $\begin{array}{cl}\text { Biaya Penilaian (Appraisal Cost) } \\
\text { - } \quad \text { Inspeksi dan Pengujian...... } \\
\text { - } \quad \text { Pengendalian Pemasok...... } \\
\text { - } \quad \text { Pengendalian Pengukuran...... } \\
\text { - } \quad \text { Penggunaan Material untuk Peneilaian..... } \\
\text { - } \quad \text { Audit Kualitas Internal..... } \\
\text { Biaya Total Penilaian (Total Appraisal Costs) } \\
\end{array}$ & & \\
\hline $\begin{array}{cl}\text { Biaya Kegagalan Internal (Internal Failure Costs) } \\
\text { - } \quad \text { Material Terbuang (Scrap).... } \\
\text { - } \quad \text { Perbaikan Ulang atau Pengerjaan Ulang.... } \\
\text { - } \quad \text { Inspalisis Kegagalan Internal.... } \\
\text { - Downtime Mesin.... } \\
\text { - } \quad \text { Downgrading atas Produk..... } \\
\text { Biaya Total Kegagalan Internal (Total Internal Failure Cost) }\end{array}$ & & \\
\hline $\begin{array}{l}\text { Biaya Kegagalan Eksternal (External Failure Costs) } \\
\text { • Kegagalan Dalam Penjualan } \\
\text { - } \quad \text { Biaya Penggantian Dalam Masa Jaminan } \\
\text { - } \quad \text { Analisis Kegagalan Eksternal } \\
\text { Biaya Total Dalam Kegagalan Eksternal (Total External Failure } \\
\text { Cost) }\end{array}$ & & \\
\hline $\begin{array}{l}\text { Biaya Total Kualitas (Total Quality Costs) } \\
\text { Basis : } \\
\text { Biaya Tenaga Kerja Langsung } \\
\text { Harga Pokok Penjualan.... } \\
\text { Penjualan Total } \\
\text { Rasio : } \\
\text { Rasio Biaya Total Kegagalan Internal Terhadap Biaya Tenaga Kerja } \\
\text { Langsung } \\
\text { Rasio Biaya Kualitas Terhadap Harga Pokok Penjualan } \\
\text { Rasio Biaya Kualitas Terhadap Penjualan Total }\end{array}$ & & \\
\hline
\end{tabular}

Sumber : Ariani, Dorothea Wahyu, Manajemen Kualitas Pendekatan Sisi Kualitatif, Ghalia Indonesia, Jakarta, 2003, hal. 31

Untuk mengimbangi manfaat-manfaat ini, ada tiga kelemahan dari informasi biaya kualitas yang seharusnya diakui. Pertama, hanya mengukur dan melaporkan biaya kualitas tidak akan memecahkan masalah 
kualitas apapun. Masalah hanya dapat diselesaikan dengan mengambil tindakan. Kedua, hasilnya ketinggalan di belakang program perbaikan kualitas. Pada awalnya kualitas total dapat meningkat ketika system pengendalian kualitas di desain dan ditempatkan. Penurunan di biayabiaya ini tidak akan terjadi sampai program kualitas telah memberikan pengaruh 1 tahun atau lebih. Dan ketiga, biaya kualitas yang paling penting, kehilangan penjualan dari konsumen yang kecewa, biasanya diabaikan dari laporan biaya kualitas karena hal itu sangat sulit doperkirakan.

Khususnya, selama tahun-tahun pertama dari program perbaikan kualitas, keuntungan dari penyusunan laporan biaya kualitas lebih banyak dari pada biayanya dan keterbatasan dari laporan tersebut. Ketika para manajer memperoleh pengalaman dalam menyeimbangkan aktivitas pencegahan dan penilaian, kebutuhan akan laporan biaya kualitas sering kali menurun.

Peningkatan kualitas pada perusahaan merupakan kegiatan pokok perusahaan dalam rangka meningkatkan produk yang dihasilkan. Peningkatan kualitas menitikberatkan pada fitness for use (cocok untuk digunakan) dan mengurangi tingkat defect. Peningkatan fitness for use dapat memberikan manfaat penting seperti kualitas yang lebih bagus bagi konsumen, peningkatan pangsa pasar bagi perusahaan, peningkatan produktifitas dan lainnya.

"Bagaimana perusahaan dapat mengurangi biaya kualitas? jawabannya tergantung bagaimana biaya kualitas didistribusikan”.

Keefektifan peningkatan kualitas dapat dinilai dari berbagai segi, yaitu : Peningkatan kualitas dikatakan efektif apabila kenaikan biaya dan biaya penilaian lebih kecil daripada penurunan biaya kegagalan, dan peningkatan kualitas dikatakan efektif jika tujuan tercapai yaitu bebas produk cacat (zero defect) dan rasio biaya kualitas tidak lebih dari 2,5\% terhadap penjualan, sedang beberapa pakar mutu berpendapat 2 sampai 4 persen dari penjualan. Standar kerusakan tidak lebih dari 2,5\% dari penjualan aktual telah banyak diterima oleh pakar kualitas dan banyak perusahaan yang telah menerapkannya.

Keefektifan peningkatan kualitas dapat dilihat dari efisiensi penggunaan sumber daya dan penurunan produk cacat serta diikuti penurunan biaya kualitas. Melihat pentingnya kualitas produk bagi perusahaan. Maka pengukuran keefektifan peningkatan kualitas sangat diperlukan untuk 
mengetahui apakah usaha yang dilakukan oleh perusahaan telah efektif atau belum.

Jadi berdasarkan pembahasan dari definisi diatas dapat disimpulkan bahwa biaya kualitas adalah biaya-biaya yang dikeluarkan oleh perusahaan dalam rangka meningkatkan kualitas produk atau mencapai standar yang telah ditetapkan, yang terdiri dari biaya pencegahan, biaya penilaian, biaya kegagalan internal, dan biaya kegagalan eksternal.

\section{Penjualan}

Sebenarnya definisi penjualan cukup luas, beberapa ahli menyebutkan sebagai ilmu dan beberapa yang lain menyebutkannya sebagai seni.Penjualan adalah ilmu dan seni mempengaruhi pribadi yang dilakukan oleh penjual untuk mengajak orang agar bersedia membeli barang atau jasa yang ditawarkannya.

Menurut Soemarso (2004) pengertian Penjualan adalah : "Jumlah yang dibebankan kepada pembeli untuk barang dagangan yang diserahkan dan merupakan pendapatan perusahaan yang bersangkutan”

Dengan adanya penjualan, terciptanya proses pertukaran barang dan jasa antara penjual dan pembeli. Agar pertukaran barang dan jasa tercipta sesuai dengan tujuan yang diharapkan perusahaan, maka pelaksanaan penjualan harus terkoordinir dengan baik dan harus dimanajemen dengan baik. Manajemen penjualan ada yang mengartikan sebagai seni atau merupakan seni untuk mencapai terciptanya proses pertukaran barang dan jasa.

Prosedur Penjualan adalah urutan kegiatan sejak diterimanya pesanan dari pembeli, pengiriman barang, pembuatan faktur (penagihan), dan pencatatan penjualan.

Berdasarkan pembahasan definisi di atas, secara sederhana dapat dikatakan bahwa penjualan merupakan tujuan utama perusahaan, dengan pengertian bahwa yang dimaksud penjualan adalah pengalihan hak kepemilikan atas barang atau jasa dari pihak penjual kepada pembeli yang disertai dengan penyerahan imbalan atau pembelian dari pihak penerima barang atau jasa kepada pihak penjual sebagai timbal balik atas 
penyerahan barang atau jasa tersebut. Dan menurut aktivitasnya penjualan dibagi menjadi dua, yaitu penjualan tunai dan penjualan kredit.

Dalam dunia usaha dewasa ini, kualitas telah menjadi bagian dari strategi bisnis untuk meningkatkan keunggulan bersaing. Kualitas dan produktivitas merupakan senjata utama bagi perusahaan dalam bersaing di lingkungan yang selalu berubah. Perhatian khusus pada kualitas didasarkan pada kenyataan bahwa kualitas yang meningkat akan meningkatkan penjualan perusahaan, karena peningkatan kualitas ini akan diiringi oleh biaya yang terus menerus dan naiknya pangsa pasar.

Dalam rangka pelaksanaan program peningkatan kualitas, perusahaan harus tetap memperhatikan efisiensi biaya, dimana perusahaan mampu menghasilkan produk yang berkualitas namun dengan harga jual yang kompetiif. Penurunan biaya tidak semata-mata merupakan pengurangan biaya produksi, namun juga beberapa pengurangan aktivitas-aktivitas berlebih tanpa mengorbankan kualitas produk yang dihasilkan.

Para pionir kualitas membuat penelitian tentang aspek ekonomi tentang kualitas jauh melebihi biayanya. Peningkatan kualitas dapat memberikan kepercayaan kepada pelanggan dan pada akhirnya mendorong peningkatan penjualan atau meningkatkan loyalitas konsumen pada produk yang dipasarkan.

Perusahaan dapat melakukan perencanaan biaya kualitas di masa yang akan datang dengan cara membuat standar biaya kualitas yang dapat ditentukan dengan mencari tingkat optimum dari biaya kualitas pada periode lalu. Dengan melakukan perencanaan biaya kualitas perusahaan bisa menekan pengeluaran untuk biaya kualitas tetapi tetap menghasilkan produk yang berkualitas pula sehingga penjualan pun akan terus meningkat.

\section{Kerangka Pikir Penelitian}

Dalam penelitian ini menggunakan beberapa variabel, yaitu variabel bebasnya adalah biaya pencegahan, biaya penilaian, biaya kegagalan internal, dan biaya kegagalan eksternal dan variabel terikatnya adalah penjualan . Hubungan antar variabel tersebut dapat digambarkan dalam sebuah kerangka pikir dibawah ini. 


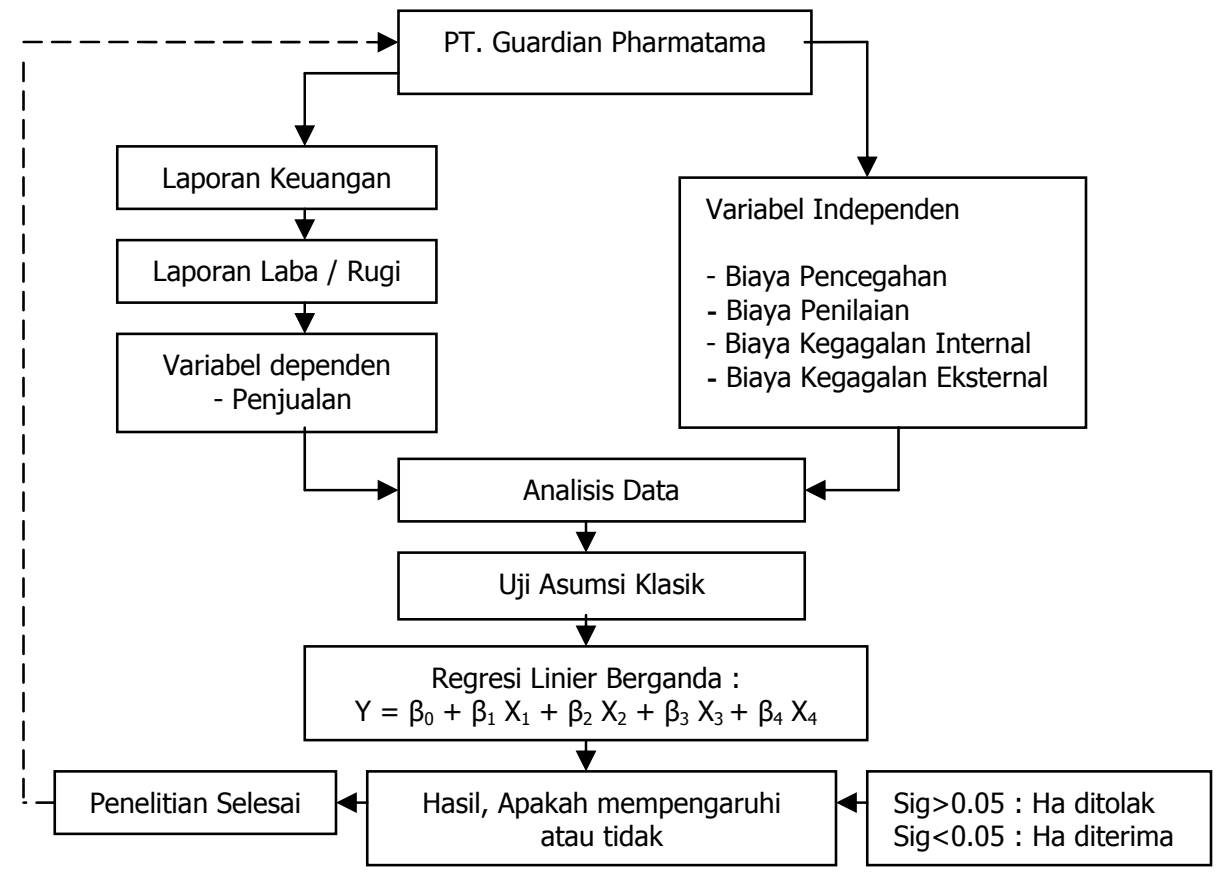

Gambar 1. Kerangka Pikir Penelitian

Keterangan gambar :

Berdasarkan kajian teori, penelitian ini mencakup pengamatan terhadap aktivitas kualitas dan penjualan yang dilakukan perusahaan. Dari data laporan tersebut diperoleh dan dianalisis variabel-variabel yang mempengaruhi nilai penjualan.

Variabel-variabel tersebut adalah :

a. Biaya kualitas yaitu biaya yang dikeluarkan perusahaan dalam rangka meningkatkan kualitas produk atau mencapai standar yang telah ditetapkan yang terdiri dari biaya pencegahan, biaya penilaian, biaya kegagalan internal, dan biaya kegagalan eksternal.

b. Penjualan yaitu aktivitas penjualan yang dilakukan perusahaan.

Kedua variabel ini akan dianalisis dan diuji pengaruhnya terhadap penjualan dengan menggunakan analisis regresi berganda. Kesimpulan yang diperoleh dari analisis ini akan dijadikan umpan balik atau feed back kepada perusahaan.Garis putus-putus yang ditunjukkan pada gambar 
kerangka pikir diartikan bahwa hasil analisis yang dilakukan boleh diterima atau ditolak oleh Perusahaan.

Hipotesis

Berdasarkan uraian diatas maka hipotesis penelitian yang akan diajukan adalah sebagai berikut :

$H_{1}$ Apakah terdapat pengaruh antara biaya pencegahan terhadap tingkat penjualan.

$\mathrm{H}_{2}$ Apakah terdapat pengaruh antara biaya penilaian terhadap tingkat penjualan.

$\mathrm{H}_{3}$ Apakah terdapat pengaruh antara biaya kegagalan internal terhadap tingkat penjualan.

$\mathrm{H}_{4}$ Apakah terdapat pengaruh antara biaya kegagalan eksternal terhadap tingkat penjualan.

$\mathrm{H}_{5}$ Apakah terdapat pengaruh antara biaya pencegahan, biaya penilaian, biaya kegagalan internal, \& biaya kegagalan eksternal secara bersama-sama terhadap tingkat penjualan.

\section{POPULASI DAN SAMPEL}

\section{Populasi}

Populasi adalah keseluruhan unsur yang terdapat di dalam objek penelitian.Unsur tersebut dapat berupa orang,benda, perusahaan, atribut atau unit-unit apa saja yang terkandung dalam objek penelitian. Populasi yang digunakan dalam penelitian ini adalah semua data mengenai biaya kualitas dan penjualan.Selama perusahaan itu melakukan kegiatan usahanya yaitu dari tahun 2004-2008.

\section{Sampel}

Sampel adalah bagian dari populasi yang menjadi objek penelitian yang dianggap mewakili kondisi atau keadaan populasi. Sedangkan jenis sampel yang digunakan adalah sampel jenuh, serta sampel ini agar dapat dilakukan secara lebih mendalam dan terfokus maka sampel ini hanya dibatasi pada laporan biaya kualitas dan penjualan bulanan PT. Guardian Pharmatama pada tahun 2004 sampai dengan tahun 2008. 
Tabel 2. Definisi Operasional Variabel

\begin{tabular}{|c|c|c|c|}
\hline Variabel & Definisi & Pengukuran & Skala \\
\hline $\begin{array}{l}\text { Dependen } \\
\mathrm{Y}=\text { Penjualan }\end{array}$ & $\begin{array}{l}\text { Jumlah Barang yang dijual ke } \\
\text { konsumen sesuai harga yang } \\
\text { telah ditetapkan }\end{array}$ & Jumlah x harga & Nominal \\
\hline Independen & & & \\
\hline X1 = Biaya Pencegahan & $\begin{array}{l}\text { Biaya yang dikeluarkan untuk } \\
\text { pelatihan, dan perencanaan } \\
\text { kualitas. }\end{array}$ & $\begin{array}{l}\text { Biaya Pelatihan }+ \text { Biaya } \\
\text { Perencanaan } \\
\text { Aktual }\end{array}$ & Nominal \\
\hline X2 = Biaya Penilaian & $\begin{array}{l}\text { Biaya yang dikeluarkan untuk } \\
\text { Inspeksi dan Pengujian, \& } \\
\text { Pemeliharaan Ketetapan Alat } \\
\text { Pengujian Kualitas. }\end{array}$ & $\begin{array}{l}\text { Biaya Inspeksi } \begin{array}{r}\text { \& } \\
\text { Pengujian }+\end{array} \text { Biaya } \\
\text { Pemeliharaan } \quad \text { Ketetapan } \\
\text { Alat Pengujian } \text { Kualitas } \\
\text { Aktual }\end{array}$ & Nominal \\
\hline $\begin{array}{l}\text { X3 = Biaya Kegagalan } \\
\text { Internal }\end{array}$ & $\begin{array}{l}\text { Biaya yang dikeluarkan untuk } \\
\text { sisa bahan, pengerjaan ulang, } \\
\text { dan pengujian kembali. }\end{array}$ & $\begin{array}{l}\text { Biaya Sisa Bahan + Biaya } \\
\text { Pengerjaan Ulang + Biaya } \\
\text { Pengujian Kembali Aktual }\end{array}$ & Nominal \\
\hline $\begin{array}{l}\text { X4 = Biaya Kegagalan } \\
\text { Eksternal }\end{array}$ & $\begin{array}{l}\text { Biaya yang dikeluarkan untuk } \\
\text { retur barang. }\end{array}$ & Biaya Retur Barang Aktual & Nominal \\
\hline
\end{tabular}

Sumber : Diolah Penulis

\section{Sejarah PT. Guardian Pharmatama}

PT. Guardian Pharmatama merupakan industri PMDN (Penanaman Modal Dalam Negeri) yang didirikan tahun 1992 yang menggantikan industri farmasi Hasto Husodo. Kantor pusat PT. Guardian Pharmatama terletak di Komplek Green Ville Maisonette Blok FA 18-19 Jakarta dan pabriknya berlokasi di kawasan industri manis, Jl. Manis Raya, Gandasari, Jatiuwung, Tangerang 15136, Banten.

\section{Visi dan Misi Perusahaan}

Mengembangkan secara terus menerus produk farmasi dan pelayanan untuk memenuhi kebutuhan konsumen demi masa depan perusahaan dan memberikan hasil yang layak bagi stake holder.

Misi Perusahaan yaitu memberikan produk yang berkualitas dan layanan terbaik kepada konsumen, menjaga kepercayaan masyarakat dan kualitas produk sebagai komitmen perusahaan serta memperhatikan keluhan masyarakat.

Adapun motto dari PT. Guardian Pharmatama adalah "Quality is our concern" 


\section{Aktivitas Ekonomi Perusahaan}

PT. Guardian Pharmatama mamahami hal-hal tersebut dan mencoba turut berperan aktif dalam bentuk mengantisipasi serta mewujudkannya, sehingga PT. Guardian Pharmatama telah menerapkan CPOB dalam pembuatan produk-produknya.Hal ini dapat dilihat dari sertifikat СРОВ yang telah diperoleh. Sebagai konsekuensi ketatnya persaingan serta permintaan di bidang industri farmasi, PT. Guardian Pharmatama menciptakan berbagai macam produk yang bisa bersaing di pasar yang kesemuanya memenuhi standar СРОB yang telah ditetapkan. Adapun produk-produk yang dihasilkan PT. Guardian Pharmatama dapat dilihat pada table berikut.

Saat ini, kapasitas produksi yang dihasilkan oleh PT. Guardian Pharmatama adalah 960 Batch produk / tahun, yang mencakup produk Antibiotika, Gastrointestinal, Anti Alergi, Cerebrovaskular, Analgesik \& Anti Piretik, Other, Vitamin, Suplemen, Respiratori, Metabolisme, Dermatologi, NSAID, dan Psikiatri. Keunggulan-keunggulan yang ditawarkan oleh produk PT. Guardian Pharmatama ialah mengutamakan mutu, mulai dari pemilihan bahan baku sampai dengan hasil akhir. Setiap tahap pengerjaan melalui proses kontrol yang sangat ketat,sehingga setiap produk yang diterima konsumen terjamin kualitasnya.Hasil-hasil produksi yang dihasilkan PT. Guardian Pharmatama tidak bisa langsung dijual ketangan konsumen akhir (end user) hasil-hasil produksi tersebut harus dijual melalui distributor-distributor farmasi.

Seperti yang telah dilakukan PT. Guardian Pharmatama dengan menjual produk ke distributor-distributor baik nasional maupun lokal yaitu:

Tabel 3. Daftar Distributor PT. Guardian Pharmatama

\begin{tabular}{|l|l|}
\hline \multicolumn{1}{|c|}{ Distributor Nasional } & \multicolumn{1}{|c|}{ Distributor Lokal } \\
\hline 1. PT. Millenium Pharmacon International & 1. PT. Sarana Biomeditama Irja \\
2. PT. Kalista Prima & 2. PT. Perintis Bina Utama Farmasi \\
3. PT. Penta Valent & 3. PT. Indomarta Primatama \\
& 4. PT. Gidion Jaya \\
& 5. PT. Kimia Farma \\
& 6. PT. Setia Tenoch \\
\hline
\end{tabular}

Sumber : PT. Guardian Pharmatama 
Tabel 4. Daftar Produk PT. Guardian Pharmatama

\begin{tabular}{|c|c|c|}
\hline $\begin{array}{l}\text { Produk Antibiotika } \\
\text { 1. Leomoxyl Kapsul \& } \\
\text { Sirup } \\
\text { 2. Ciflos Tablet } \\
\text { 3. Q-Cef Kapsul \& Sirup } \\
\text { 4. Indanox Kapsul } \\
\text { 5. Genicol Tablet } \\
\text { 6. Zibramax Tablet } \\
\text { 7. Cephaflox Injeksi } \\
\text { 8. Goforan Injeksi } \\
\text { 9. Lefos Tablet } \\
\text { 10. Nufirom Injeksi } \\
\text { 11. Nucef Kapsul \& Sirup }\end{array}$ & \begin{tabular}{l}
\multicolumn{2}{c}{ Produk Dermatologi } \\
1. Elox Krim \\
2. Lamodex Krim \\
3. Thecort Krim \\
4. Fungasol Tablet \& \\
Shampo \\
5. Govazol Tablet \\
6. Fuladic Krim \\
7. Nuface Krim \\
8. Fungares Krim \\
9. Forcanox Tablet \\
10. Genolon Krim
\end{tabular} & $\begin{array}{l}\quad \text { Produk Suplemen } \\
\text { 1. Procur Kapsul } \\
\text { 2. Dhavit Sirup } \\
\text { 3. Nuvision Tablet } \\
\text { 4. Nulacta Kapsul } \\
\text { 5. Anadium Tablet } \\
\text { 6. Nulacta Plus Kapsul } \\
\text { 7. Liparin Kapsul } \\
\text { 8. Nuzym Kapsul } \\
\text { 9. Nufit Tablet \& Sirup } \\
\text { 10. Ironyl Tablet }\end{array}$ \\
\hline 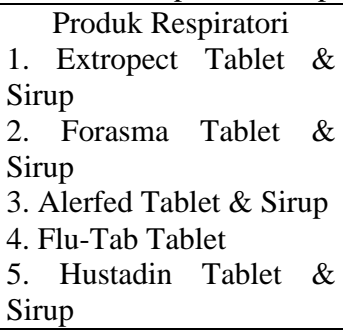 & $\begin{array}{l}\text { Produk Gastrointestinal } \\
\text { 1. Galflux Tablet } \\
\text { 2. Norsec Kapsul } \\
\text { 3. Opox Tablet } \\
\text { 4. Guarposid Tablet } \\
\text { 5. Stromag Tablet }\end{array}$ & $\begin{array}{l}\text { Produk Analgesik \& Anti Piretik } \\
\text { 1. Cupanol Suspensi } \\
\text { 2. Profen Sirup } \\
\text { 3. Ponsamic Tablet } \\
\text { 4. Maganol Tablet } \\
\text { 5. Goralgin Tabl }\end{array}$ \\
\hline $\begin{array}{l}\text { Produk Metabolisme } \\
\text { 1. Evothyl Kapsul } \\
\text { 2. Eraphage Tablet } \\
\text { 3. Glamarol Tablet } \\
\text { 4. Lopiten Tablet }\end{array}$ & $\begin{array}{l}\text { Produk Cerebrovascular } \\
\text { 1. Unalium Tablet } \\
\text { 2. Exergin Tablet } \\
\text { 3. Goclid Tablet } \\
\text { 4. Naletal Tablet } \\
\text { 5. Gotropil Tablet \& Injeksi } \\
\text { 6. Galepsi Tablet } \\
\end{array}$ & $\begin{array}{l}\quad \text { Produk Anti Alergi } \\
\text { 1. Oxtin Tablet } \\
\text { 2. Loran Tablet } \\
\text { 3. Rydian Tablet }\end{array}$ \\
\hline \multirow[t]{2}{*}{$\begin{array}{l}\text { Produk Others } \\
\text { 1. Copal Balsem } \\
\text { 2. Stenirol Tablet } \\
\text { 3. K T M Injeksi } \\
\text { 4. Forelax Tablet } \\
\text { 5. Ursolic Kapsul }\end{array}$} & \multirow[t]{2}{*}{$\begin{array}{l}\text { Produk Psik } \\
\text { 1. Alganax Tablet } \\
\text { 2. Rizodal Tablet } \\
\text { 3. Govotil Tablet } \\
\text { 4. Nudep Tablet }\end{array}$} & $\begin{array}{l}\text { Produk Vitamin } \\
\text { 1. Neurohax Tablet } \\
\text { 2. Emibion Kapsul } \\
\text { 3. Ethigobal Tablet }\end{array}$ \\
\hline & & $\begin{array}{l}\text { Produk NSAID } \\
\text { 1. Goflex Tablet } \\
\text { 2. Pilopil Tablet } \\
\text { 3. Exaflam Tablet } \\
\text { 4. Iremax Tablet }\end{array}$ \\
\hline
\end{tabular}

Sumber : PT. Guardian Pharmatama

\section{Data Perkembangan Usaha}

Dengan menghasilkan kualitas produk yang semakin baik, maka penjualan pun akan dapat mengalami peningkatan. Dapat dilihat dalam laporan penjualan yang dimiliki PT. Guardian Pharmatama dari tahun 2004 sampai dengan tahun 2008 per bulannya mengalami peningkatan setiap tahunnya. 
Sehingga dari meningkatnya hasil penjualan maka dapat memberikan keuntungan pula bagi perusahaan. Berikut ini tabel yang menggambarkan penjualan yang diperoleh dari data PT. Guardian Pharmatama.

Tabel 5. Data Penjualan PT. Guardian Pharmatama

\begin{tabular}{|c|c|c|c|c|c|}
\hline Periode & $\begin{array}{c}2004 \\
\text { ( Rp ) }\end{array}$ & $\begin{array}{c}2005 \\
\text { ( Rp ) }\end{array}$ & $\begin{array}{c}2006 \\
\text { ( Rp ) }\end{array}$ & $\begin{array}{c}2007 \\
\text { ( Rp ) }\end{array}$ & $\begin{array}{c}2008 \\
(\mathrm{Rp})\end{array}$ \\
\hline Januari & $5,222,454,200$ & $6,415,989,600$ & $7,333,016,600$ & $9,834,282,050$ & $11,431,209,700$ \\
\hline Pebruari & $4,950,955,300$ & $5,955,628,050$ & $8,278,623,500$ & $9,950,619,850$ & $11,801,975,400$ \\
\hline Maret & $7,026,097,100$ & $7,209,995,050$ & $8,867,956,100$ & $9,762,853,200$ & $10,642,775,400$ \\
\hline April & $5,525,862,350$ & $6,139,931,300$ & $8,198,466,600$ & $10,889,867,600$ & $12,911,241,700$ \\
\hline Mei & $6,736,941,650$ & $6,030,335,200$ & $8,042,266,700$ & $10,999,813,800$ & $11,074,807,300$ \\
\hline Juni & $5,357,086,500$ & $7,868,445,200$ & $8,102,057,800$ & $10,483,493,500$ & $13,508,689,800$ \\
\hline Juli & $5,400,744,500$ & $6,343,540,900$ & $8,178,341,200$ & $10,027,911,300$ & $12,430,550,900$ \\
\hline Agustus & $6,710,381,000$ & $6,941,973,400$ & $8,249,915,100$ & $10,143,404,900$ & $12,749,214,800$ \\
\hline September & $6,897,074,500$ & $7,564,287,100$ & $8,292,134,100$ & $11,124,791,100$ & $13,381,728,600$ \\
\hline Oktober & $6,539,931,300$ & $8,628,316,100$ & $9,580,516,900$ & $10,718,801,300$ & $13,514,067,200$ \\
\hline November & $6,030,335,200$ & $7,257,912,300$ & $8,118,231,700$ & $12,218,751,100$ & $12,214,878,600$ \\
\hline Desember & $7,868,445,200$ & $8,693,004,000$ & $8,381,315,650$ & $11,348,902,300$ & $13,545,928,050$ \\
\hline TOTAL & $74,266,308,800$ & $85,049,358,200$ & $99,622,841,950$ & $127,503,492,000$ & $149,207,067,450$ \\
\hline
\end{tabular}

Sumber : PT. Guardian Pharmatama

\section{PEMBAHASAN}

\section{Penerapan Biaya Kualitas Pada PT. Guardian Pharmatama}

Berdasarkan hasil pengamatan dan data-data perusahaan yang ada, berikut ini adalah aktivitas-aktivitas yang berhubungan dengan biaya kualitas yang dikeluarkan oleh PT. Guardian Pharmatama dalam usaha mempertahankan dan meningkatkan kualitas produknya, yaitu :

\section{a. Biaya Pencegahan}

Biaya Pencegahan merupakan biaya yang dikeluarkan untuk mencegah terjadinya cacat dalam produk yang dihasilkan oleh perusahaan.

Dari data yang ada di perusahaan, biaya yang terjadi karena kegiatan pencegahan adalah sebagai berikut :

1) Pelatihan

Meliputi biaya program persiapan pelatihan untuk mencapai dan memperbaiki kualitas tanpa memperdulikan departemen mana yang mendapat pelatihan, serta biaya pelaksanaan program tersebut.

2) Perencanaan Kualitas 
Biaya ini timbul di perusahaan karena berkaitan dengan aktifitas perencanaan kualitas secara keseluruhan termasuk juga penyiapan prosedur-prosedur yang diperlukan untuk mengkomunikasikan rencana kualitas ke seluruh pihak yang berkepentingan dalam rangka mencapai sasaran kualitas.

Terdapat ketidaksesuaian antara teori dengan data yang ada diperusahaan, hal itu dikarenakan tidak semua biaya yang termasuk didalam biaya pencegahan terjadi di PT. Guardian Pharmatama.

b. Biaya Penilaian

Biaya penilaian merupakan biaya yang dikeluarkan untuk menentukan apakah produk telah memenuhi persyaratan kualitas yang telah ditetapkan. Dari data yang ada di perusahaan, biaya yang terjadi karena kegiatan penilaian adalah sebagai berikut :

1) Inspeksi dan Pengujian

Biaya ini dapat dipisahkan menjadi biaya inspeksi, pengujian laboratorium dan pengujian laporan.

2) Pemeliharaan Ketetapan Alat Pengujian Kualitas

Merupakan biaya pengoperasian sistem untuk menjaga peralatan dan perlengkapan penguji selalu akurat.

Terdapat ketidaksesuaian antara teori dengan data yang ada diperusahaan, hal itu dikarenakan tidak semua biaya yang termasuk didalam biaya penilaian terjadi di PT. Guardian Pharmatama.

c. Biaya Kegagalan Internal

Biaya kegagalan internal adalah biaya yang dikeluarkan karena terjadinya ketidaksesuaian produk dengan spesifikasi kualitas yang telah ditetapkan namun sudah dapat dideteksi sebelum produk dikirim ke pelanggan.

Dari data yang ada di perusahaan, biaya yang terjadi karena kegagalan internal adalah sebagai berikut :

1) Sisa Bahan

Merupakan kerugian bersih atas tenaga kerja dan bahan baku akibat adanya produk rusak yang secara ekonomis tidak dapat diperbaiki atau digunakan.

2) Pengerjaan Ulang

Merupakan biaya yang dikeluarkan untuk memperbaiki produk cacat sehingga memenuhi persyaratan.

3) Pengujian Kembali 
Biaya yang dikeluarkan untuk inspeksi dan pengujian kembali produk rusak yang telah diperbaiki.

Terdapat ketidaksesuaian antara teori dengan data yang ada diperusahaan, hal itu dikarenakan tidak semua biaya yang termasuk didalam biaya kegagalan internal terjadi di PT. Guardian Pharmatama.

\section{d. Biaya Kegagalan Eksternal}

Biaya kegagalan eksternal adalah biaya yang dikeluarkan karena terjadinya ketidaksesuaian produk dengan spesifikasi kualitas yang telah ditetapkan, namum baru dapat dideteksi setelah produk berada ditangan pelanggan.

Dari data yang ada di perusahaan, biaya yang terjadi karena kegagalan eksternal adalah sebagai berikut :

Terjadinya Retur Barang, merupakan seluruh biaya yang berkaitan dengan penerimaan dan penggantian produk rusak yang diterima dari distributor.

Terdapat ketidaksesuaian antara teori dengan data yang ada diperusahaan, hal itu dikarenakan tidak semua biaya yang termasuk didalam biaya kegagalan eksternal terjadi di PT. Guardian Pharmatama.

\section{Pengaruh Biaya Kualitas Terhadap Penjualan.}

Biaya kualitas yang dikeluarkan oleh setiap perusahaan dimaksudkan untuk meningkatkan kualitas produk karena kualitas berkaitan dengan pengidentifikasian, perbaikan dan pencegahan produk rusak. Dengan menghasilkan kualitas produk yang semakin baik, maka penjualan pun akan dapat mengalami peningkatan. Penjualan tersebut meningkat karena adanya pembelian ulang, adanya pembelian baru, maupun pembelian baru yang beralih dari perusahaan lain. PT. Guardian Pharmatama dalam rangka meningkatkan kualitas produk yang dihasilkan mengharuskan perusahaan mengeluarkan biaya kualitas seperti biaya pencegahan, biaya penilaian, biaya kegagalan internal, biaya kegagalan eksternal dengan tujuan untuk meningkatkan penjualan. Dapat dilihat dalam laporan penjualan yang dimiliki PT. Guardian Pharmatama dari tahun 2004 sampai dengan tahun 2008 per bulannya mengalami peningkatan setiap tahunnya , sehingga dari meningkatnya hasil penjualan maka dapat memberikan keuntungan pula bagi perusahaan.

\section{Pengujian Model Penelitian}

1. Uji Normalitas Data 
Uji normalitas ini bertujuan untuk mengetahui distribusi data dalam variabel yang akan digunakan dalam penelitian. Data yang baik dan layak digunakan dalam penelitian adalah data yang memiliki distribusi normal.

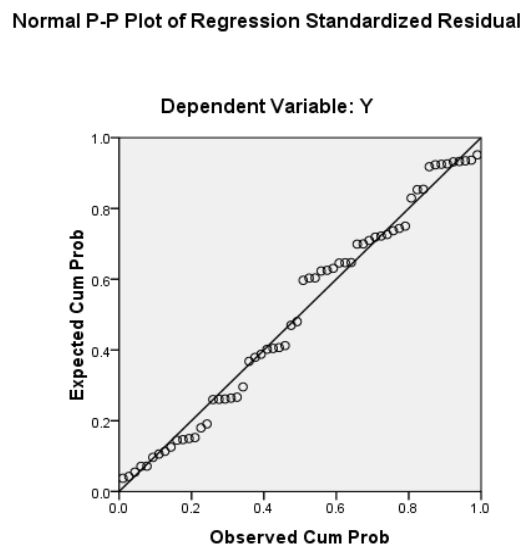

Gambar 2. Pengujian Normalitas Logaritma Natural

Analisis :

Berdasarkan gambar diatas, terlihat titik-titik menyebar disekitar garis diagonal, serta penyebarannya mengikuti garis diagonal. Dengan demikian model regresi berganda adalah baik dan layak dipakai untuk prediksi penjualan berdasarkan masukan variabel bebasnya yaitu biaya pencegahan, biaya penilaian, biaya kegagalan internal, dan biaya kegagalan eksternal.

\section{Uji Multikolinearitas}

Uji multikolinearitas bertujuan untuk mengetahui ada tidaknya variabel independen yang memiliki kemiripan dengan variabel independen lain dalam satu model. Kemiripan antar variabel independen dalam satu model akan menyebabkan terjadinya korelasi yang sangat kuat antara suatu variabel independen dengan variabel independen yang lainnya. 
Tabel 6. Hasil Pengujian Multikolinearitas

Coefficients (a)

\begin{tabular}{|l|l|c|c|}
\hline Model & & \multicolumn{2}{|c|}{ Collinearity Statistics } \\
\hline & & Tolerance & VIF \\
\hline 1 & (Constant) & & \\
& X1 & .521 & 1.198 \\
& X2 & .567 & 1.764 \\
& X3 & .158 & 6.334 \\
& X4 & .154 & 6.489 \\
& & & \\
\hline
\end{tabular}

a.Dependent Variable : $Y$

Analisis :

Pada tabel 6 hasil pengujian pada penelitian menunjukkan bahwa :

1. Pada penelitian ke-1 biaya pencegahan (X1) memiliki angka VIF yaitu 1,198 dan nilai tolerance yaitu 0,521.

2. Pada penelitian ke-2 menunjukkan bahwa biaya penilaian (X2) memiliki angka VIF yaitu 1,764 dan nilai tolerance yaitu 0,567.

3. Pada penelitian ke-3 menunjukkan bahwa biaya kegagalan internal (X3) memiliki angka VIF yaitu 6,334 dan nilai tolerance yaitu 0,158.

4. Pada penelitian ke-4 menunjukkan bahwa biaya kegagalan eksternal (X4) memiliki angka VIF yaitu 6,489 dan nilai tolerance yaitu 0,154.

Dengan demikian dapat disimpulkan model regresi pada variabel biaya pencegahan, biaya penilaian, biaya kegagalan internal, dan biaya kegagalan eksternal tidak terdapat masalah multikolinearitas, karena nilai VIF lebih kecil dari 10 dan nilai tolerance lebih besar dari 0,1.

3. Uji Heteroskedastisitas

Uji heteroskedastisitas bertujuan untuk menguji apakah dalam sebuah model regresi terjadi ketidaksamaan varians dari satu pengamatan ke pengamatan lain. Jika varians dari residual atau sama dalam suatu pengamatan ke pengamatan lain tetap, maka disebut homoskedastisitas. Sementara, apabila varians berbeda disebut heteroskedastisitas. Model regresi yang baik dan layak dipakai adalah yang tidak terjadi heteroskedastisitas. 




Analisis :

Gambar 3. Grafik Pengujian Heteroskedastisitas

Berdasarkan gambar 3 diatas dapat dilihat titik-titik yang ada tidak membentuk sebuah pola tertentu yang jelas. Serta tersebar baik diatas maupun dibawah angka nol ( 0 ) pada sumbu Y (regression standarlized residual). Hal ini berarti tidak terjadi heteroskedastisitas pada model regresi berganda. Sehingga model regresi berganda baik dan layak dipakai untuk prediksi penjualan berdasarkan masukan variabel bebasnya yaitu biaya pencegahan, biaya penilaian, biaya kegagalan internal, dan biaya kegagalan eksternal.

4. Uji Autokorelasi

Uji autokorelasi dalam suatu model bertujuan untuk mengetahui ada tidaknya korelasi antara variabel penggangu pada periode tertentu dengan variabel penggangu periode sebelumnya. Autokorelasi sering terjadi pada sampel dengan data time series dengan n-sampel adalah periode tertentu.

\section{Hasil Pengujian Autokorelasi}

Analisis :

Pada tabel 7, Hasil uji autokorelasi dengan Durbin-Watson menunjukkan angka 0.466 yaitu diantara 2 sampai 2 . Hal ini membuktikan tidak ada autokorelasi dalam model regresi ini. 
Tabel 7. Model Summary ${ }^{\mathrm{b}}$

\begin{tabular}{|l|r|r|r|r|r|}
\hline Model & \multicolumn{1}{|c|}{$\mathrm{R}$} & R Square & \multicolumn{1}{c|}{$\begin{array}{c}\text { Adjusted R } \\
\text { Square }\end{array}$} & $\begin{array}{c}\text { Std. Error of the } \\
\text { Estimate }\end{array}$ & Durbin-Watson \\
\hline 1 & $.975^{\mathrm{a}}$ & .950 & .947 & $5.68780 \mathrm{E} 8$ & .466 \\
\hline
\end{tabular}

a. Predictors: (Constant), X4, X2, X1, X3

b. Dependent Variable: $Y$

\section{Analisis Regresi Linear Berganda}

Maksud dari analisis regresi ini adalah untuk menganalisis besarnya hubungan dan pengaruh variabel independen yang jumlahnya lebih dari dua dan variabel dependen dikenal dengan analisis regresi berganda. Untuk lebih dari dua variabel independen maka untuk memudahkan mencari koefisien regresinya dapat dibantu dengan komputer menggunakan SPSS.

Tabel 8. Hasil Analisis Regresi Linear Berganda

Coefficients(a)

\begin{tabular}{|l|l|r|r|r|r|r|}
\hline Model & & $\begin{array}{c}\text { Unstandardized } \\
\text { Coefficients }\end{array}$ & & $\begin{array}{c}\text { Standardized } \\
\text { Coefficients }\end{array}$ & $\mathrm{t}$ & Sig. \\
\hline & & $\mathrm{B}$ & Std. Error & Beta & & \\
\hline 1 & (Constant) & -240710057.3 & 753037705.882 & & -0.320 & 0.750 \\
& X1 & 496.753 & 131.845 & 0.157 & 3.768 & 0.000 \\
& X2 & 411.237 & 39.131 & 0.420 & 10.509 & 0.000 \\
& X3 & 38.384 & 4.972 & 0.585 & 7.720 & 0.000 \\
& X4 & 21.283 & 10.309 & 0.158 & 2.064 & 0.044 \\
\hline
\end{tabular}

a. Dependent Variable: $Y$

Analisis :

Pada tabel 8 , dapat dilihat bahwa besarnya nilai perhitungan regresi menunjukkan konstanta adalah sebesar -240710057,3 dan koefesien arah regresi X1 adalah sebesar 496,753, X2 adalah sebesar 411,237, X3 adalah sebesar 38,384, dan X4 adalah sebesar 21,283 untuk mencari pengaruh biaya kualitas terhadap penjualan dapat diketahui dengan rumus : $\mathrm{Y}=\mathrm{a}$ 
+b1X1+b2X2+b3X3+b4X4. Berdasarkan hasil tersebut dapat diperoleh persamaan regresi berganda sebagai berikut :

$$
Y=-240710057,3+496,753 X 1+411,237 X 2+38,384 X 3+21,283 X 4
$$

Jika biaya pencegahan $(\mathrm{X} 1)=0$, biaya penilaian $(\mathrm{X} 2)=0$, biaya kegagalan internal $(\mathrm{X} 3)=0$, dan biaya kegagalan eksternal $(\mathrm{X} 4)=0$, maka nilai penjualan sebesar - 240710057,3. Jika biaya pencegahan (X1) bertambah 1 rupiah, maka nilai penjualan akan naik sebesar 496,753 unit dengan asumsi ceteris paribus. Jika biaya penilaian (X2) bertambah 1 rupiah, maka nilai penjualan akan naik sebesar 411,237 unit dengan asumsi ceteris paribus. Jika biaya kegagalan internal (X3) bertambah 1 rupiah, maka nilai penjualan akan naik sebesar 38,384 unit dengan asumsi ceteris paribus. Jika biaya kegagalan eksternal (X4) bertambah 1 rupiah, maka nilai penjualan akan naik sebesar 21,283 unit dengan asumsi ceteris paribus. Dari persamaan regresi tersebut dapat dilihat bahwa :

$>$ Pengaruh biaya pencegahan ( X1 ) terhadap penjualan adalah positif (searah), yang berarti bahwa penurunan (kenaikan) biaya pencegahan akan mengakibatkan penurunan (kenaikan) terhadap penjualan (berbanding lurus).

$>$ Pengaruh biaya penilaian ( X2 ) terhadap penjualan adalah positif (searah), yang berarti bahwa penurunan (kenaikan) biaya penilaian akan mengakibatkan penurunan (kenaikan) terhadap penjualan (berbanding lurus).

$>$ Pengaruh biaya kegagalan internal ( X3 ) terhadap penjualan adalah positif (searah), yang berarti bahwa penurunan (kenaikan) biaya kegagalan internal akan mengakibatkan penurunan (kenaikan) terhadap penjualan (berbanding lurus).

$>$ Pengaruh biaya kegagalan eksternal ( X4 ) terhadap penjualan adalah positif (searah), yang berarti bahwa penurunan (kenaikan) biaya kegagalan eksternal akan mengakibatkan penurunan (kenaikan) terhadap penjualan (berbanding lurus).

6. Koefesien Determinasi

Koefisien determinasi digunakan untuk melihat besar pengaruh variabel independen terhadap variabel dependen dalam model regresi.

Analisis : 
Dari hasil perhitungan diatas diperoleh $\mathrm{R}$ Square disebut juga koefisien determinasi adalah sebesar 0,950. Berarti $95 \%$ perubahan variabel penjualan dipengaruhi oleh perubahan pada variabel biaya pencegahan, variabel biaya penilaian, variabel biaya kegagalan internal, dan variabel biaya kegagalan eksternal, sisanya sebesar $5 \%$ perubahan variabel penjualan dipengaruhi oleh faktor lain diluar variabel biaya pencegahan, variabel penilaian, variabel kegagalan internal, dan biaya kegagalan eksternal.

Tabel 9. Hasil Analisis Koefisien eterminasi

\begin{tabular}{l}
\begin{tabular}{|l|c|c|c|c|r|}
\hline $\begin{array}{l}\text { Mod } \\
\text { el }\end{array}$ & $\mathrm{R}$ & $\begin{array}{c}\mathrm{R} \\
\text { Square }\end{array}$ & $\begin{array}{c}\text { Adjusted R } \\
\text { Square }\end{array}$ & $\begin{array}{c}\text { Std. Error } \\
\text { of the } \\
\text { Estimate }\end{array}$ & $\begin{array}{c}\text { Durbin- } \\
\text { Watson }\end{array}$ \\
\hline 1 & $.975^{\mathrm{a}}$ & .950 & .947 & $5.68780 \mathrm{E} 8$ & .466 \\
\hline
\end{tabular} \\
\hline
\end{tabular}

b. Dependent Variable: $Y$

\section{Uji t}

T-test bertujuan untuk mengetahui besarnya pengaruh masing-masing variabel independen secara individual (parsial) terhadap variabel dependen. Hasil uji ini pada output SPSS dapat dilihat pada tabel coefficients. Jika nilai signifikan atau probabilitas lebih kecil dari 0,05 berarti terdapat pengaruh signifikan antara variabel independen terhadap variabel dependen. Sebaliknya, jika nilai signifikasi lebih besar dari 0,05 berarti tidak terdapat pengaruh signifikan antara variabel independen terhadap variabel dependen.

Tabel 10. Hasil Uji t

Coefficients(a)

\begin{tabular}{|l|l|r|r|r|r|r|}
\hline Model & & $\begin{array}{c}\text { Unstandardized } \\
\text { Coefficients }\end{array}$ & & $\begin{array}{c}\text { Standardized } \\
\text { Coefficients }\end{array}$ & $\mathrm{t}$ & Sig. \\
\hline \multirow{3}{*}{1} & & $\mathrm{~B}$ & Std. Error & \multicolumn{1}{c|}{ Beta } & & \\
& (Constant) & -240710057.3 & 753037705.882 & & -0.320 & 0.750 \\
& X1 & 496.753 & 131.845 & 0.157 & 3.768 & 0.000 \\
& X2 & 411.237 & 39.131 & 0.420 & 10.509 & 0.000 \\
& X3 & 38.384 & 4.972 & 0.585 & 7.720 & 0.000 \\
& X4 & 21.283 & 10.309 & 0.158 & 2.064 & 0.044 \\
\hline
\end{tabular}

a. Dependent Variable: $Y$ 
Analisis :

Pada tabel diatas berdasarkan nilai signifikasi untuk :

> Hasil pengujian hipotesis penelitian ke-1 menunjukkan bahwa biaya pencegahan ( X1 ) memiliki tingkat signifikasi sebesar 0.000 berarti Ha diterima. Sehingga dapat disimpulkan bahwa biaya pencegahan berpengaruh secara signifikan terhadap penjualan.

$>\quad$ Hasil pengujian hipotesis penelitian ke-2 menunjukkan bahwa biaya penilaian ( X2 ) memiliki tingkat signifikasi sebesar 0.000 berarti Ha diterima. Sehingga dapat disimpulkan bahwa biaya penilaian berpengaruh secara signifikan terhadap penjualan.

> Hasil pengujian hipotesis penelitian ke-3 menunjukkan bahwa biaya kegagalan internal ( X3 ) memiliki tingkat signifikasi sebesar 0.000 berarti Ha diterima. Sehingga dapat disimpulkan bahwa biaya kegagalan internal berpengaruh secara signifikan terhadap penjualan.

$>\quad$ Hasil pengujian hipotesis penelitian ke-4 menunjukkan bahwa biaya kegagalan eksternal ( X4 ) memiliki tingkat signifikasi sebesar 0.044 berarti Ha diterima. Sehingga dapat disimpulkan bahwa biaya kegagalan eksternal berpengaruh secara signifikan terhadap penjualan.

\section{Uji F}

Uji simultan dengan F-test ini bertujuan untuk mengetahui pengaruh bersama-sama variabel independen terhadap variabel dependen. Hasil Ftest ini pada output SPSS dapat dilihat pada tabel ANOVA.

Tabel 11. Hasil Uji F

ANOVA $^{\mathrm{b}}$

\begin{tabular}{|c|c|c|c|c|c|c|}
\hline \multicolumn{2}{|c|}{ Model } & $\begin{array}{l}\text { Sum of } \\
\text { Squares }\end{array}$ & $\mathrm{df}$ & Mean Square & $\mathrm{F}$ & Sig. \\
\hline \multirow[t]{3}{*}{1} & Regression & $3.391 \mathrm{E} 20$ & 4 & 8.478E19 & 262.056 & $.000^{\mathrm{a}}$ \\
\hline & Residual & $1.779 \mathrm{E} 19$ & 55 & 3.235E17 & & \\
\hline & Total & 3.569E20 & 59 & & & \\
\hline
\end{tabular}

a. Predictors: (Constant), X4, X2, X1, X3

b. Dependent Variable: $Y$ 
Analisis :

Berdasarkan tabel 11 terlihat signifikasinya sebesar 0.000 yang memiliki nilai lebih kecil dari 0,05. Hal ini berarti bahwa biaya pencegahan, biaya penilaian, biaya kegagalan internal, dan biaya kegagalan eksternal secara bersama-sama berpengaruh secara signifikan terhadap penjualan.

Berdasarkan hasil perhitungan analisis biaya kualitas dengan penjualan pada objek penelitian PT. Guardian Pharmatama, dengan menggunakan analisis regresi kita dapat mengetahui bahwa pengaruh biaya pencegahan, biaya penilaian, biaya kegagalan internal, dan biaya kegagalan eksternal terhadap penjualan adalah positif, yang artinya bahwa kenaikan biaya kualitas akan mengakibatkan kenaikan terhadap penjualan. Hal tersebut dapat dilihat dari koefisien regresi atau nilai b1X1 dalam persamaan tersebut menunjukkan angka positif sebesar 496,753 yang berarti bahwa setiap 1 kenaikan biaya pencegahan (X1) akan diikuti dengan kenaikan penjualan sebesar 496,753 unit. Nilai b2X2 dalam persamaan tersebut menunjukkan angka positif sebesar 411,237 yang berarti bahwa setiap 1 kenaikan biaya penilaian (X2) akan diikuti dengan kenaikan penjualan sebesar 411,237 unit. Nilai b3X3 dalam persamaan tersebut menunjukkan angka positif sebesar 38,384 yang berarti bahwa setiap 1 kenaikan biaya kegagalan internal (X3) akan diikuti dengan kenaikan penjualan sebesar 38,384 unit. Nilai b4X4 dalam persamaan tersebut menunjukkan angka positif sebesar 21,283 yang berarti bahwa setiap 1 kenaikan biaya kegagalan eksternal (X4) akan diikuti dengan kenaikan penjualan sebesar 21,283 unit. Demikian juga sebaliknya. Sementara nilai koefisien a yaitu sebesar - 240710057,3 berarti apabila tidak terdapat kenaikan atau penurunan pada biaya kualitas maka diperkirakan tingkat penjualan sebesar - 240710057,3.

Persamaan regresi memperlihatkan bagaimana biaya pencegahan, biaya penilaian, biaya kegagalan internal, dan biaya kegagalan eksternal mempengaruhi penjualan. Hasil dari analisis regresi linear berganda adalah sebagai berikut :

$\mathrm{Y}=-240710057,3+496,753 \mathrm{X} 1+411,237 \mathrm{X} 2+38,384 \mathrm{X} 3+21,283 \mathrm{X} 4$ , dan dapat digunakan untuk memprediksi besar kecilnya nilai penjualan yang akan dimiliki oleh perusahaan dengan tingkat laba yang diinginkan perusahaan. Jika menggunakan analisa BEP kita bisa meramalkan berapa besar jumlah biaya pencegahan, biaya penilaian, biaya kegagalan internal, 
dan biaya kegagalan eksternal. Biaya yang dikeluarkan pun harus dilaksanakan lebih efektif lagi dengan memperbesar biaya pencegahan dan biaya penilaian, karena kedua biaya ini yang berpengaruh besar terhadap penjualan serta memperkecil biaya kegagalan internal dan kegagalan eksternal, karena kedua biaya ini yang berpengaruh sedikit terhadap penjualan dan berpotensi menimbulkan kerugian bagi perusahaan, agar dapat meningkatkan penjualan bagi perusahaan sehingga dari meningkatnya hasil penjualan maka dapat memberikan keuntungan pula bagi perusahaan. Persamaan tersebut menunjukkan bahwa pengaruh biaya pencegahan, biaya penilaian, biaya kegagalan internal, dan biaya kegagalan eksternal terhadap penjualan adalah positif (searah), yang artinya bahwa kenaikan biaya kualitas akan mengakibatkan kenaikan terhadap penjualan (berbanding lurus). Dan pada pengujian signifikasi koefesien regresi ternyata diperoleh hasil yang signifikan. Pengaruh biaya pencegahan, biaya penilaian, biaya kegagalan internal, dan biaya kegagalan eksternal terhadap penjualan diketahui melalui koefesien determinasi $(\mathrm{Kd})$, yaitu sebesar 0,95. Artinya pengaruh biaya pecegahan, biaya penilaian, biaya kegagalan internal, dan biaya kegagalan eksternal terhadap penjualan adalah sebesar $95 \%$, sementara sisanya sebesar $5 \%$ dipengaruhi oleh faktor lain diluar biaya pecegahan, biaya penilaian, biaya kegagalan internal, dan biaya kegagalan eksternal. Hasil uji regresi yang telah dilakukan terbukti hipotesis alternatif (Ha) yang dibuat diterima, yaitu :

1. Terdapat pengaruh biaya pencegahan terhadap penjualan.

2. Terdapat pengaruh biaya penilaian terhadap penjualan.

3. Terdapat pengaruh biaya kegagalan internal terhadap penjualan.

4. Terdapat pengaruh biaya kegagalan eksternal terhadap penjualan.

5. Terdapat pengaruh biaya pencegahan, biaya penilaian, biaya kegagalan internal, dan biaya kegagalan eksternal secara bersama-sama terhadap penjualan.

\section{KESIMPULAN}

Penelitian ini bertujuan untuk memberikan bukti empiris mengenai pengaruh variabel independent : biaya kualitas. Terhadap variabel dependen : penjualan. Dari hasil pembahasan dan analisis maka dapat diperoleh kesimpulan sebagai berikut : 
1. Dari hasil uji t untuk biaya pencegahan, menunjukkan tingkat signifikasi 0,000. Karena tingkat signifikasi berada dibawah 0,05, maka dapat disimpulkan bahwa biaya pencegahan berpengaruh secara signifikan terhadap penjualan.

2. Dari hasil uji t untuk biaya penilaian, menunjukkan tingkat signifikasi 0,000. Karena tingkat signifikasi berada dibawah 0,05, maka dapat disimpulkan bahwa biaya penilaian berpengaruh secara signifikan terhadap penjualan.

3. Dari hasil uji t untuk biaya kegagalan internal, menunjukkan tingkat signifikasi 0,000. Karena tingkat signifikasi berada dibawah 0,05, maka dapat disimpulkan bahwa biaya kegagalan internal berpengaruh secara signifikan terhadap penjualan.

4. Dari hasil uji t untuk biaya kegagalan eksternal, menunjukkan tingkat signifikasi 0,044. Karena tingkat signifikasi berada dibawah 0,05, maka dapat disimpulkan bahwa biaya kegagalan eksternal berpengaruh secara signifikan terhadap penjualan.

5. Dari hasil uji F untuk biaya pencegahan, biaya penilaian, biaya kegagalan internal, dan biaya kegagalan eksternal, menunjukkan tingkat signifikasi 0,000 Karena tingkat signifikasi berada dibawah 0,05, maka dapat disimpulkan bahwa biaya pencegahan, biaya penilaian, biaya kegagalan internal, dan biaya kegagalan eksternal berpengaruh secara signifikan terhadap penjualan.

6. Dari hasil analisa regresi diperoleh persamaan regresi linear berganda

$Y=-240710057,3+496,753$ X1 + 411,237 X2 + 38,384 X3 + 21,283

X4.

Persamaan regresi tersebut menunjukkan bahwa pengaruh biaya pencegahan, biaya penilaian, biaya kegagalan internal, dan biaya kegagalan eksternal terhadap penjualan adalah positif yang berarti kenaikan biaya kualitas akan mengakibatkan kenaikan pula terhadap penjualan.

7. Hasil uji koefisien determinasi (Kd) menunjukkan biaya kualitas memiliki kontribusi terhadap penjualan sebesar $95 \%$ sedangkan sisanya sebesar $5 \%$ dipengaruhi oleh faktor-faktor lain selain biaya kualitas.

\section{Saran}

Setelah penelitian ini dilakukan, saran yang diberikan adalah sebagai berikut : 
1. Bagi perusahaan sebaiknya lebih meningkatkan lagi program peningkatan kualitas produknya dari waktu ke waktu sehingga produk yang akan dihasilkan akan semakin baik sesuai dengan keinginan, kebutuhan, dan kepuasan pelanggan. Laporan biaya kualitas selalu dibuat setiap periode sehingga dapat membantu pihak menajemen dalan mengambil kebijakan yang berhubungan dengan peningkatan kualitas produk perusahaan dan biaya yang dikeluarkan pun harus dilaksanakan lebih efektif lagi dengan memperbesar biaya pencegahan dan biaya penilaian serta memperkecil biaya kegagalan internal dan kegagalan eksternal, agar dapat meningkatkan penjualan bagi perusahaan.

2. Dalam penelitian ini hanya difokuskan pada satu variabel saja, yaitu biaya kualitas yang mempengaruhi penjualan. Sedangkan variabel lain tidak diperhatikan. Penjualan merupakan tujuan utama dari perusahaan dan penjualan tersebut dipengaruhi oleh banyak faktor. Maka dari itu, untuk penelitian-penelitian selanjutnya harus diteliti lebih dari satu variabel X bukan hanya biaya kualitas saja.

3. Bila dihubungkan dengan target perolehan laba perusahaan dengan terlebih dahulu menentukan BEP, maka dalam penelitian selanjutnya kita dapat menentukan jumlah biaya pencegahan, biaya penilaian, biaya kegagalan internal, dan biaya kegagalan eksternal pada tingkat penjualan tertentu sesuai laba yang diinginkan oleh perusahaan.

\section{DAFTAR PUSTAKA}

Anindita, Rina., \& Hasyim. (2009). Prinsip-Prinsip Dasar Metode Riset Bidang Pemasaran. (1st ed.). Jakarta: UIEU-University Press.

Ariani, Dorothea Wahyu. (2003). Manajemen Kualitas Pendekatan Sisi Kualitatif. Jakarta: Ghalia Indonesia.

Curter, William K., \& Usry, Milton E. (2005). Akuntansi Biaya (15th ed.). Jakarta: Salemba Empat.

Garrison, Ray H., Noreen, Eric W., \& Brewer, Peter C. (2006). Akuntansi Manajerial. (11th ed.). Jakarta: Salemba Empat. 
Gasverz Vincent S.Z. (2006). Total Quality Management Untuk Praktisi Bisnis dan Industri. Jakarta: PT.Gramedia Pustaka Utama.

Hansen, Don R., \& Mowen, Marryane M. (2005). Akuntansi Manajemen (7th ed.). Jakarta: Salemba Empat.

Sekaran, Uma. (2006). Metode Penelitian Untuk Bisnis (4th ed.). Jakarta: Salemba Empat.

Soemarso, S.R., (2004). Akuntansi Manajerial Suatu Pengantar (5th ed.). Jakarta: Salemba Empat.

Sugiyono. (2005). Metode Penelitian Bisnis. Bandung: Alfabeta.

Supranto, J. (2004). Ekonometrika. Buku Kedua. Jakarta: Ghalia Indonesia.

Suryadi, K., \& Purwanto S. (2004). Statistika Untuk Ekonomi \& Keuangan Modern. Edisi 2. Salemba Empat. 